\title{
Expanding the Scope of Polyoxometalates as Artificial Proteases towards Hydrolysis of Insoluble Proteins
}

\author{
[a] Dr. N. D. Savić, D. E. Salazar Marcano, Prof. Dr. T. N. Parac-Vogt \\ Department of Chemistry \\ KU Leuven \\ Celestijnenlaan 200F, 3001 Leuven, Belgium \\ E-mail: tatjana.vogt@kuleuven.be \\ 1 Authors contributed equally to this work
}

Nada D. Savić, ${ }^{[a] 1}$ David E. Salazar Marcano, ${ }^{[a] 1}$ and Tatjana N. Parac-Vogt*[a]

Supporting information for this article is given via a link at the end of the document.

\begin{abstract}
Despite the enormous importance of insoluble proteins in biological processes, their structural investigation remains a challenging task. Development of artificial enzymatic catalysts would greatly facilitate elucidation of their structure as currently used enzymes in proteomics largely lose activity in the presence of surfactants, which are necessary to solubilize insoluble proteins. In this study the hydrolysis of a fully insoluble protein by a polyoxometalate complex as an artificial protease in surfactant solutions is reported for the first time. The hydrolysis of zein as a model protein was investigated in the presence of $\mathrm{Zr}(\mathrm{IV})$-substituted Keggin-type polyoxometalate (POM), $\left(\mathrm{Et}_{2} \mathrm{NH}_{2}\right)_{10}\left[\mathrm{Zr}\left(\alpha-\mathrm{PW}_{11} \mathrm{O}_{39}\right)_{2}\right]$, and different concentrations of the anionic surfactant sodium dodecyl sulfate (SDS). The selective hydrolysis of the protein upon incubation with the catalyst was observed, and the results indicate that hydrolytic selectivity and activity of the POM catalysts strongly depends on the concentration of surfactant. The molecular interactions between the POM catalyst and zein in the presence of SDS were explored using a combination of spectroscopic techniques which indicated competitive binding between POM and SDS towards the protein. The formation of micellar superstructures in tertiary POM/surfactant/protein solutions has been confirmed by electrical conductivity and Dynamic Light Scattering.
\end{abstract}

\section{Introduction}

Proteins are among the most important molecules on Earth since they play an essential role in all living organisms, [1,2] and their structural investigation is crucial in order to understand their biological functions. [3] Hence, determining and understanding the structure of proteins is highly important in a variety of fields such as drug design and disease prediction, among many others.[4] However, research so far has mostly focused on the study of water-soluble proteins while insoluble proteins remain relatively unexplored leaving a large gap in the current knowledge of their properties.

From a pharmacological point of view, insoluble proteins, which include a large family of membrane proteins, are highly important since they play key roles in biological functions, their disruption can lead to several diseases - such as cystic fibrosis and they represent the main targets for around $70 \%$ of currently used drugs in medicine.[5-8] Therefore, it is vital to understand their structure activity relationship as well as how they can be targeted by specific substrates.[7,9] However, of all known protein structures less than $1 \%$ correspond to insoluble proteins.[1,3] Consequently, elucidating the structure of these insoluble proteins can also be valuable in the discovery of novel therapeutic targets.[5]

The solubility and functionality of proteins can be affected by their folding state, since functional folded proteins involved in different biological processes have their own unique threedimensional structure, which depends on their secondary structure.[1] As a result, misfolding of proteins can decrease their solubility, and this can lead to severe health problems. For example, misfolding resulting in overexposure of hydrophobic patches in proteins, among other external factors, can lead to the formation of insoluble aggregates which are known to be responsible for many neurodegenerative diseases like Parkinson's, Alzheimer's, and Huntington's disease.[1,2,10] Therefore, in order to develop therapeutic strategies and to address disease-relevant issues the structure of insoluble misfolded proteins should be explored further.

The study of protein structure and function, known as proteomics, is typically performed by hydrolyzing them into smaller fragments which can be subsequently analyzed by mass spectrometry.[1] One of the main challenges in the field of proteomics is that the investigation of insoluble proteins is largely underrepresented and limited because of their hydrophobic nature and complex structure.[3,11] Due to the high stability of the peptide bond which links the amino acids in proteins, a catalyst is needed to accelerate the process of hydrolysis and this is often achieved using naturally existing enzymes which can selectively cleave peptide bonds in proteins. These enzymes typically act as homogeneous catalysts in aqueous solutions, but the use of surfactants is often essential to solubilize normally insoluble proteins since surfactants can act as mediators between the hydrophobic regions of proteins and the aqueous environment. However, enzymes, such as trypsin, which are typically used to hydrolyze proteins for proteomics analyses, largely lose their catalytic activity in the presence of surfactants.[12,13] In addition, trypsin selectively hydrolyzes proteins mainly at cleavage sites with lysine or arginine residues, which are often lacking in highly hydrophobic insoluble proteins.[14] Hence, the development of novel peptidases that can retain their hydrolytic activity in the presence of surfactants is essential to facilitate the study of insoluble proteins. 
Previous works from our group have shown that metalsubstituted polyoxometalates can be used as artificial metalloproteases that are able to selectively hydrolyze a wide variety of globular water-soluble proteins under mild experimental conditions.[15] Polyoxometalates (POMs) are inorganic polynuclear metal-oxo anionic clusters with a diverse range of properties of interest in different fields (catalysis, medicine, analytical chemistry, and materials science) since they can vary in shape, size, solubility, redox potential, and acidity.[16-20] For hydrolytic purposes the most frequently employed POMs are the Keggin, Wells-Dawson and Lindqvist structure-types with Lewis acidic metals such as $\mathrm{Zr}(\mathrm{IV}), \mathrm{Hf}(\mathrm{IV})$ or $\mathrm{Ce}(\mathrm{IV})$ embedded into the structure. These metal-substituted POMs are homogeneous catalysts which possess a net negative charge, and therefore they can selectively interact in solution with positively charged patches of proteins via electrostatic interactions. Taking advantage of these interactions, the selective hydrolysis of a range of several water-soluble proteins - with different size, composition, and isoelectric point $(\mathrm{pl})$ - promoted by POMs has been established by our group.[15] Furthermore, it was found that the catalytic activity of metal-substituted POMs is preserved in surfactant solutions, where the hydrolysis of peptides and different watersoluble globular proteins,[12,21-23] as well as of a partially soluble unstructured protein has been observed.[24] These studies revealed that hydrolytic activity and selectivity of the POMs depend on the structure of the protein substrate, as well as on the structure, polarity and charge of surfactants.

The knowledge gained from these promising results sets the platform for the exploration of POMs as artificial proteases for the hydrolysis of fully insoluble proteins, which has not been demonstrated before and thereby expands the applicability of POMs as artificial proteases to an even wider range of proteins. The insolubility of many proteins is often due to a high content of solvent-exposed hydrophobic amino acids, and, therefore, zein an insoluble protein isolated from corn - was chosen as a representative model since more than $50 \%$ of its amino acids are hydrophobic in nature.[25,26] These hydrophobic amino acids form nine a-helical hydrophobic chains connected via polar asparagine and glutamine loops that are solvent-exposed.[27] Bearing in mind its hydrophobicity, zein is insoluble in water and it is only soluble in alcohols, highly basic solutions or in the presence of anionic detergents, while even common non-ionic or zwitterionic surfactants cannot be used to dissolve zein.[26] Furthermore, its interactions with surfactants have been previously studied in the context of determining the potential skinirritating effects of surfactants due to its similarity to keratin, an insoluble protein present in the skin.[28]

The hydrolysis of zein, as a model insoluble protein, was investigated in the presence of the anionic surfactant sodium dodecyl sulfate (SDS), one of the most commonly used surfactants for the solubilization of membrane proteins (Figure 1 (a)).[9] $\mathrm{Zr}(\mathrm{IV})$-substituted Keggin-type POM ((Et $\left.{ }_{2} \mathrm{NH}_{2}\right)_{10}[\mathrm{Zr}(\alpha-$ $\left.\mathrm{PW}_{11} \mathrm{O}_{39}\right)_{2}$ ]; $\mathbf{Z r}-\mathrm{K} \mathrm{1:2}$ ) was used to promote the hydrolysis reaction since it has been previously shown to be active in the hydrolysis of several water-soluble proteins (Figure 1 (b)).[22-24] (a)
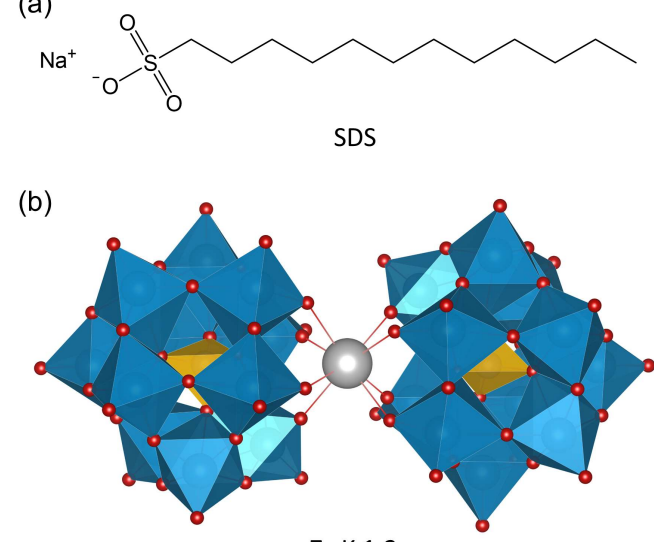

Zr-K 1:2

Figure 1. (a) Skeletal representation of sodium dodecyl sulfate (SDS). (b) Mixed ball-and-stick and polyhedral representation of $\left(\mathrm{Et}_{2} \mathrm{NH}_{2}\right)_{10}[\mathrm{Zr}(\alpha-$ $\left.\left.\mathrm{PW}_{11} \mathrm{O}_{39}\right)_{2}\right]$ ( $\mathrm{Zr}-\mathrm{K} \mathrm{1:2}$ ) composed of a $\mathrm{Zr}(\mathrm{IV})$ metal center, in grey, coordinated to two lacunary Keggin structures with oxygen in red, $\left\{\mathrm{WO}_{6}\right\}$ octahedra in blue and $\left\{\mathrm{PO}_{4}\right\}$ tetrahedra in yellow.

\section{Results and Discussion}

\section{Hydrolysis of Zein in the presence of different concentrations of Zr-K 1:2 \& SDS}

The molecular weight $(\mathrm{Mw})$ of zein varies from 22 to $27 \mathrm{kDa}$ on average and its isoelectric point is 6.228.[25] Zein consists of four subunits: $\alpha$ dimer (22; $19 \mathrm{kDa}), \beta$ (15 kDa), y (27; $16 \mathrm{kDa})$, and $\delta(10 \mathrm{kDa})$, which can be separated by sodium dodecyl sulfate-polyacrylamide gel electrophoresis (SDS-PAGE), and which differ in solubility, charge, and molecular weight.[29] The major component of zein is the $\alpha$-subunit, which corresponds to around $75-85 \%$ of the total protein. The second most abundant zein fraction is $\gamma$-zein which is rich in cysteine residues, while $\beta$ zein, and $\delta$-zein are rich in methionine.[30]

The enzymatic hydrolysis of zein has been previously reported, but many of the currently existing procedures typically require highly alkaline conditions, the use of organic solvents and/or reducing and alkylating agents to break disulfide bonds and facilitate hydrolysis.[31-38] Moreover, they often produce very short peptide fragments that could not be clearly separated therefore hindering further analysis of the protein structure. $[37,38]$ Hydrolysis using trypsin in aqueous alkaline solutions has also been reported, but this only produced small amounts of two peptide fragments.[32,39] In view of these findings, it is clear that artificial proteases that can selectively hydrolyze insoluble proteins under mild conditions, and produce larger and clearly distinguishable fragments, would facilitate the study of their structure in proteomics analysis. 

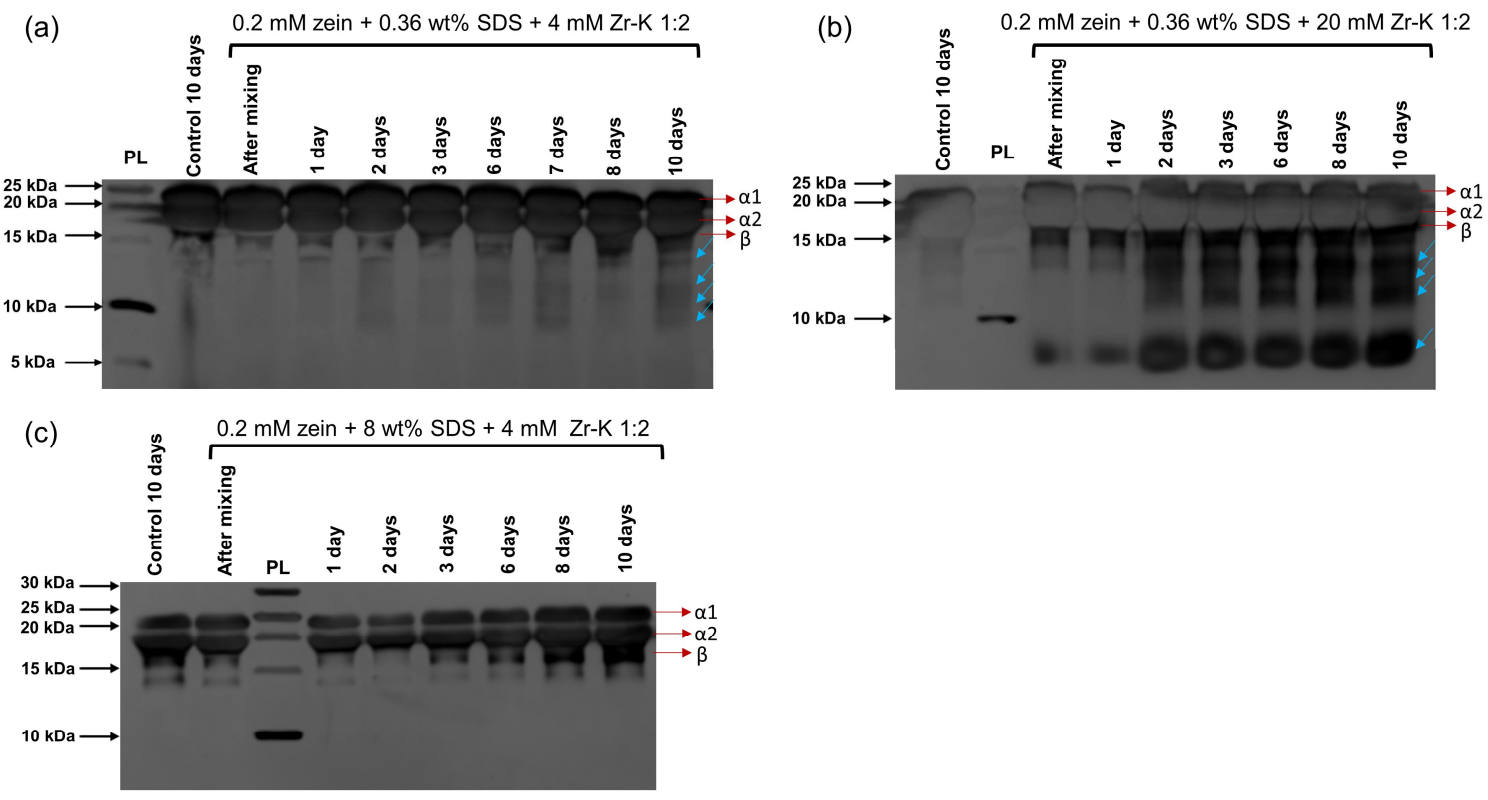

Figure 2. SDS-PAGE gel of zein $(0.2 \mathrm{mM})$ incubated in phosphate buffer $(10 \mathrm{mM}$, pH 7.4$)$ for 10 days at $60{ }^{\circ} \mathrm{C}$ in the presence of 0.36 wt $\%$ of SDS with (a) $4 \mathrm{mM}$ and (b) $20 \mathrm{mM}$ of Zr-K 1:2 as well as (c) in the presence of $8 \mathrm{wt} \%$ SDS with $4 \mathrm{mM}$ of Zr-K 1:2.

The hydrolytic experiments were performed on commercially available zein, consisting mostly of the a-subunit, which was solubilized with different concentrations of SDS $(0.36$, 3.6 and $8 \mathrm{wt} \%)$ and combined with different concentrations of catalyst, Zr-K 1:2 (4 and $20 \mathrm{mM}$ ), in order to explore the selectivity and hydrolytic activity of the catalyst under different reaction conditions and determine the influence of the surfactant concentration on the hydrolysis (Figure 2; Figure S1-3). The hydrolytic reactions were performed in a $10 \mathrm{mM}$ sodium phosphate buffer at $\mathrm{pH} 7.4$ while kept at $60^{\circ} \mathrm{C}$ and the progress was monitored for up to 10 days. In the presence of a relatively low concentration of the surfactant $(0.36 \mathrm{wt} \%$ of SDS), just above that needed to solubilize zein, 4 new fragments at lower Mw of approximately $13.2,11.1,10.6,8.4 \mathrm{kDa}$ were observed to appear in the presence of $4 \mathrm{mM} \mathrm{Zr-K} \mathrm{1:2.} \mathrm{Moreover,} \mathrm{when} \mathrm{the}$ concentration of POM was increased 5 -fold to $20 \mathrm{mM}$, the appearance of the same fragments was observed after $48 \mathrm{~h}$, which is a significant acceleration compared to non-catalyzed hydrolysis of the peptide bond.[12] Additionally, increasing the concentration of the POM from $4 \mathrm{mM}$ to $20 \mathrm{mM}$ led to hydrolytic fragments being observed earlier and also resulting in more intense bands, which suggests that more fragments were produced faster, further confirming the hydrolytic ability of the POM. This is a clear indication that hydrolysis was promoted by the presence of the POM as these fragments were not observed when the protein was incubated for the same amount of time with just $0.36 \mathrm{wt} \%$ SDS.

Several control experiments were also performed under the same conditions in order to prove that $\mathrm{Zr}-\mathrm{K} \mathrm{1:2}$ is crucial for the hydrolysis of zein. For hydrolysis reactions with either 0.36 or 3.6 wt $\%$ in the presence of and $20 \mathrm{mM}$ of trilacunary Keggin ( $\mathrm{Na}_{9}[\mathrm{~A}-$ $\left.\alpha-\mathrm{PW}_{9} \mathrm{O}_{39}\right]$ ), which lacks the $\mathrm{Zr}(\mathrm{IV})$ metal ion, no new hydrolytic fragments were observed on the SDS-PAGE gel (Figure S3).
Furthermore, the formation of insoluble gels was observed in the presence of $\mathrm{ZrOCl}_{4} \cdot 8 \mathrm{H}_{2} \mathrm{O}$, the $\mathrm{Zr}(\mathrm{IV})$ salt used for the synthesis of Zr-K 1:2, in accordance with previously reported studies.[23,4042] Consequently, the obtained results suggest that $\operatorname{Zr}(\mathrm{IV})$ is essential for the hydrolytic reaction to occur, where the POM scaffold stabilizes the $\mathrm{Zr}(\mathrm{IV})$ metal center.

Interestingly, when the concentration of the surfactant was increased 10 -fold from 0.36 to $3.6 \mathrm{wt} \%$ the selectivity of the catalyst was preserved, but the hydrolytic efficiency of the POM decreased significantly. The intensity of the bands originating from hydrolytic fragments on the SDS-PAGE gel was less pronounced, and clearly identifiable bands were not observed until after around 6 days, even when the concentration of the POM was as high as $20 \mathrm{mM}$ (Figure S1). Increasing the concentration of SDS even further to $8 \mathrm{wt} \%$ did not give any clear hydrolysis products on the SDS PAGE regardless of the concentration of the POM, indicating that protein hydrolysis was completely inhibited. (Figure 2(c); Figure S2). These findings are partly unexpected since increasing the concentration of SDS could ideally result in more efficient hydrolysis, as unfolding of the protein by the surfactant would make the cleavage sites more accessible to the POM. In order to understand the kinetic results, the nature of interactions taking place in such ternary systems was further investigated using various techniques.

\section{Influence of SDS concentration on the interactions of $\mathrm{Zr}-\mathrm{K}$ 1:2 with Zein}

Fluorescence spectroscopy is a powerful and sensitive technique used to study interactions between proteins and small molecules. Furthermore, it can be used to determine the binding affinity by detecting changes in the local environment of aromatic fluorescent residues commonly present in proteins, such as 
tryptophan (Trp), tyrosine (Tyr) and phenylalanine (Phe). Moreover, fluorescence spectroscopy can also be used for monitoring and investigating conformational changes in the protein structure.[43]

The commercially available zein used in this study mostly contains the $\alpha$-subunit with a significant amount of Tyr residues (approximately $5 \mathrm{wt} \%$ ), which have a fluorescence emission maximum around $304 \mathrm{~nm}$, while the amount of Trp and Phe residues is negligible.[44] However, as observed from the presence of additional bands in the SDS PAGE (Figure 3) commercially available zein may contain other variations of zein, such as the $\beta$-subunit which was observed as a weak band at around $16 \mathrm{kDa}$ on the SDS PAGE gel, and may contain Trp residues which have a higher absorptivity and slightly higher quantum yield than Tyr.[45,46] The interactions of $\mathbf{Z r - K}$ 1:2 with zein were studied by following the quenching of the fluorescence emission of zein with increasing amounts of $\mathrm{Zr}-\mathrm{K}$ 1:2. The binding strength, determined from the association constant $\left(K_{a}\right)$, and the number of binding molecules $(n)$ involved in the interaction leading to quenching can be calculated via the derived SternVolmer (SV) equation:

$$
\log \left(\left(\mathrm{F}_{0}-\mathrm{F}\right) / \mathrm{F}\right)=\log \left(\mathrm{K}_{\mathrm{a}}\right)+\mathrm{n} \times \log ([\mathrm{Q}])
$$

In Eq. (1), $F_{0}$ represents the unquenched fluorescence intensity in the absence of the quencher while $F$ represents the fluorescence intensity in the presence of the quencher, and [Q] is the concentration of the quencher. The fluorescence emission of zein $(0.2 \mathrm{mM})$ solubilized with different SDS concentrations $(0.36$, 3.6 and $8 w t \%)$ was observed to decrease significantly upon addition of increasing amounts of Zr-K 1:2 (0-60 $\mu \mathrm{M})$ without changing the position of the emission maximum (Figure 3; Figure S4-5). The linearity of the Stern-Volmer plot indicates a static mode of quenching due to the formation of a protein/SDS/POM complex that results in quenching of the fluorescence, which is in accordance with previously reported observations for metalsubstituted POMs and globular proteins.[47-49]
The binding affinity of $\mathrm{Zr}-\mathrm{K}$ 1:2 towards zein was found to be highest in solutions with the lowest concentration of SDS $(0.36$ wt\%) resulting in a higher $\mathrm{K}_{\mathrm{a}}$ as shown in Table 1. This can most clearly be seen for interactions with Tyr, which is a highly abundant residue throughout most of the protein structure.[44] The $K_{a}$ in presence of $0.36 \mathrm{wt} \%$ SDS $\left(28.46 \times 10^{6} \mathrm{M}^{-1}\right)$ was two orders of magnitude higher than when the concentration of SDS was $8 \mathrm{wt} \%\left(0.87 \times 10^{6} \mathrm{M}^{-1}\right)$ and the number of $\mathrm{Zr}-\mathrm{K} 1: 2$ molecules involved in binding was also significantly higher at lower concentrations of SDS. The data suggests that the micellar structure formed around the protein becomes more dense as the number of SDS molecules present in solution is increased, resulting in weaker binding of the POM catalyst, and hence lower hydrolysis of the protein.

Table 1. Binding constants $\left(K_{a}\right)$ and number of $\mathrm{Zr}-\mathrm{K}$ 1:2 bound per protein $(n)$ determined from the derived Stern-Volmer plot of the fluorescence quenching of tyrosine (Tyr) and tryptophan (Trp) residues in zein by Zr-K 1:2 in the presence of $0.36,3.6$ and $8 \mathrm{wt} \%$ of SDS $(0.2 \mathrm{mM}$ zein in $10 \mathrm{mM}$ phosphate buffer at $\mathrm{pH} 7.4$ )

\begin{tabular}{|c|c|c|c|c|c|c|}
\hline & \multicolumn{3}{|c|}{ Tyr } & \multicolumn{3}{|c|}{ Trp } \\
\hline$\%$ SDS & $n$ & $K_{a} / \cdot 10_{1}^{6} \mathrm{M}^{-}$ & $\mathrm{R}^{2}$ & $n$ & $K_{a} / \cdot 10^{6} \mathrm{M}^{-}$ & $\mathrm{R}^{2}$ \\
\hline 0.36 & 1.48 & 28.46 & 0.970 & 1.37 & 6.49 & 0.973 \\
\hline 3.6 & 1.42 & 10.06 & 0.993 & 1.38 & 5.09 & 0.992 \\
\hline 8 & 1.23 & 0.87 & 0.899 & 1.34 & 1.91 & 0.931 \\
\hline
\end{tabular}

Interestingly, differences in the $K_{a}$ and $n$ values, obtained when following changes in the emission maxima of Tyr and Trp separately, suggest that Zr-K 1:2 interacts with the local environment of both amino acids with different binding strengths. Interactions with $\operatorname{Trp}$ in general displayed a lower $K_{a}$ compared to Tyr, which is most likely due to the low abundance of Trp in zein and its specific local environment. Interestingly, $K_{a}$ and $n$ for interactions with Tyr and Trp in the presence of $8 \mathrm{wt} \%$ SDS were fairly comparable and this is likely due to the protein being largely unfolded, so that the local environment of Trp and Tyr had a less significant role in the interactions with the POM.

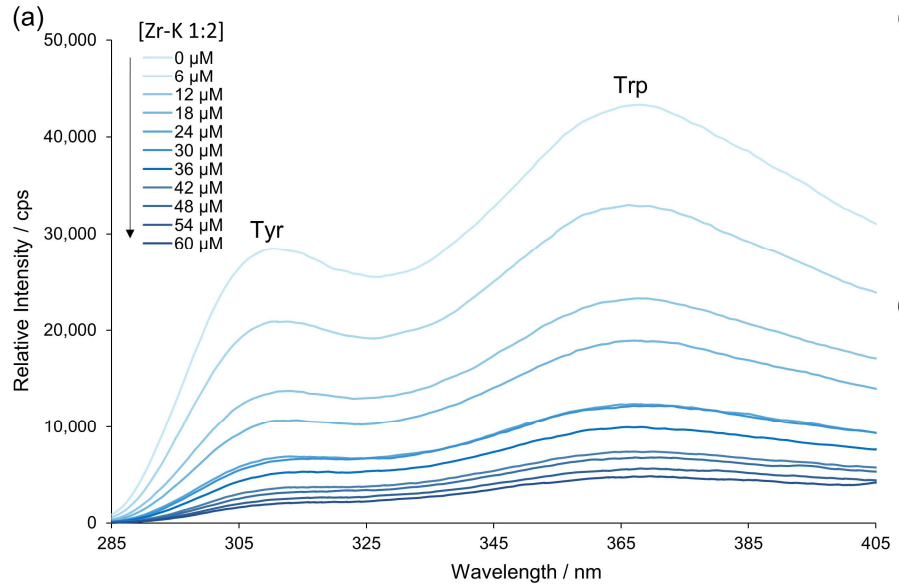

(b)

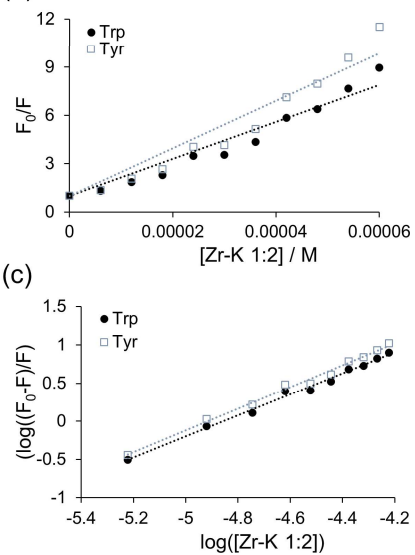

Figure 3. (a) Fluorescence emission spectra of $0.2 \mathrm{mM}$ zein in phosphate buffer at $\mathrm{pH} 7.4$ in the presence of $3.6 \mathrm{wt} \%$ SDS with increasing amounts of Zr-K 1:2 from $0 \mu \mathrm{M}$ to $60 \mu \mathrm{M}$. (b) Stern-Volmer plot of the ratio of unquenched $\left(F_{0}\right)$ and quenched $(F)$ fluorescence intensity for both tyrosine (Tyr) and tryptophan (Trp) as a function of the concentration of Zr-K 1:2 ([Zr-K 1:2]). (c) Derived Stern-Volmer plot of $\log (F o-F) / F)$ against $\log \left(\left[Z r-K\right.\right.$ 1:2]) used to determine the binding constant $\left(K_{a}\right)$ and the number of binding molecules per protein $(n)$. 
Influence of $Z r-K 1: 2$ and SDS on the Secondary Structure of Zein

Circular Dichroism (CD) spectroscopy was used to assess changes in the secondary structure of zein due to its interaction with SDS and Zr-K 1:2. Varying the amount of surfactant can change the structure of the protein and therefore influence the accessibility of the POM to the cleavage sites (Figure 4). In the CD spectrum of zein solubilized by $0.36 \mathrm{wt} \%$ of SDS two negative peaks at 208 and $222 \mathrm{~nm}$ were observed, which are characteristic of a-helical secondary structural content.[50] Upon increasing the concentration of SDS 10 -fold to $3.6 \mathrm{wt} \%$, only minor changes in the secondary structure of zein were noticed as the shape of the CD spectrum remained essentially the same. However, further increasing the concentration of SDS to $8 \mathrm{wt} \%$ resulted in much more significant changes in the secondary structure, indicating that some of the $\alpha$-helical content was lost due to a more open tertiary structure. Moreover, a slight blue shift was observed which can be an indication of more pronounced hydrophobic interactions between the hydrophobic tails of SDS molecules and hydrophobic regions of the protein.[51]

Upon addition of increasing amounts of Zr-K 1:2 to zein in the presence of SDS, the negative peak at $208 \mathrm{~nm}$ decreased towards zero and eventually disappeared while the peak at 222 $\mathrm{nm}$ only decreased slightly (Figure 5; Figure S6). This decrease in the peaks and change in the $C_{222} / C_{208}$ ratio suggests a loss of helicity due to interactions with the POM and are indicative of the disruption of intermolecular interactions between alphahelices due to unfolding of the protein structure.[52]

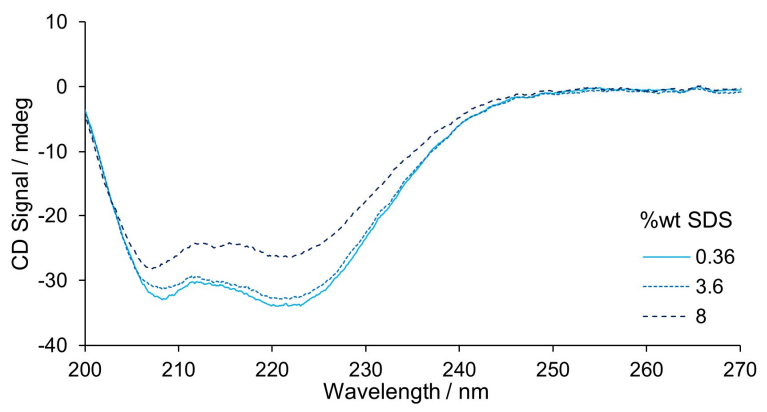

Figure 4. Far UV CD spectra of $0.02 \mathrm{mM}$ zein in the presence of $0.36,3.6$ and $8 \mathrm{wt} \%$ SDS.

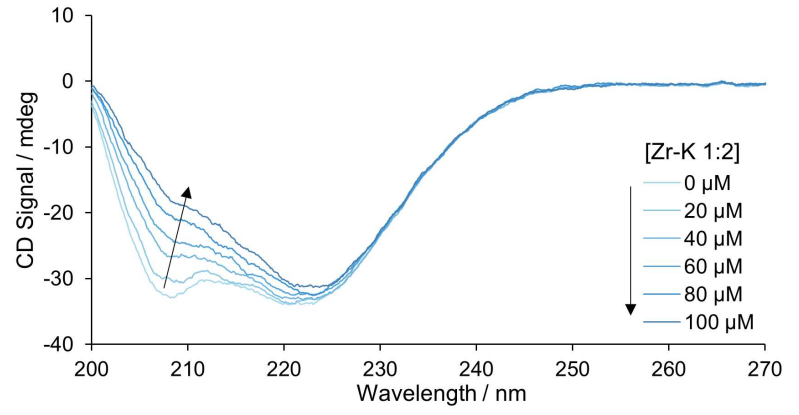

Figure 5. Far UV CD spectra of $0.02 \mathrm{mM}$ zein in the presence of $0.36 \mathrm{wt} \%$ SDS and with increasing concentrations of $\mathrm{Zr}-\mathrm{K} \mathrm{1:2}$ (from 0 to $100 \mu \mathrm{M}$ ). All solutions were in $10 \mathrm{mM}$ phosphate buffer at $\mathrm{pH} 7.4$
Unfolding of the protein may also be influenced by repulsive interactions between SDS and the negatively charged POM when both are in the vicinity of the protein surface. The red shift in the first minimum as it decreases towards zero with increasing concentration of $\mathrm{Zr}-\mathrm{K}$ 1:2 may also be due to unfolding as the local environment changes.[53]

\section{Characterization of the micellar structures in solution}

SDS is well known to form micelles in solution at concentrations above the critical micelle concentration (cmc), and the $\mathrm{cmc}$ can be influenced by the presence of other species in solution which can either favor or prevent micelle formation.[54] The $\mathrm{cmc}$ can be determined from the inflection point of a plot of conductivity against concentration of SDS (Figure 6).[54] Using this approach, the $\mathrm{cmc}$ of SDS in $10 \mathrm{mM}$ phosphate buffer at $\mathrm{pH}$ 7.4 was determined to be 0.14 wt $\%(4.8 \mathrm{mM})$, which corresponds to the value reported by Fuguet et al., and is slightly lower than that of SDS in water $(8 \mathrm{mM})$ because the presence of additional ions in solution from the buffer lowers electrostatic repulsive forces between the ionic head groups of SDS allowing for the formation of micelles at lower concentrations. $[54,55]$ Interestingly, in the presence of zein the $\mathrm{cmc}$ increased to $0.23 \mathrm{wt} \%(8.1 \mathrm{mM})$, which is due to interactions between SDS and zein that hinder the formation of micelles at lower concentrations of SDS. Additionally, the observed $\mathrm{cmc}$ coincides with the concentration at which zein fully dissolves to form a clear yellow solution, indicating that the formation of micellar structures around zein results in its solubilization. However, for concentrations between 1 and $10 \mathrm{wt} \%$, increasing the amount of SDS in solution had the same effect on the conductivity of the solution regardless of whether or not zein was present. This suggests that, as the concentration of SDS increases, zein becomes fully unfolded and saturated with surfactant so that additional amounts of SDS are not as involved in interactions with the protein since the protein had no influence on the conductivity in the range $1-10 \mathrm{wt} \%$ (Figure S7).[28]

The presence of $4 \mathrm{mM}$ of $\mathbf{Z r}-\mathrm{K} \mathrm{1:2}$ in phosphate buffer resulted in a much lower $\mathrm{cmc}$ of only $0.04 \mathrm{wt} \%(2 \mathrm{mM})$, which is due to lowering of repulsive forces between the ionic head groups of SDS as a result of the presence of additional cations in solution originating from the counter-cations of $\mathrm{Zr}-\mathrm{K}$ 1:2, which has a high negative charge (10-).[56] However, in the presence of both 0.2 $\mathrm{mM}$ zein and $4 \mathrm{mM} \mathrm{Zr-K} \mathrm{1:2} \mathrm{in} \mathrm{solution} \mathrm{a} \mathrm{higher} \mathrm{cmc}$ of $0.28 \mathrm{wt} \%$ $(9.7 \mathrm{mM})$ was observed, which indicates that interactions between SDS and zein still hinder micelle formation. Moreover, the $\mathrm{cmc}$ is even higher than for zein alone, which is likely due to competitive binding between $\mathbf{Z r - K ~ 1 : 2 ~ a n d ~ S D S ~ t o w a r d s ~ z e i n , ~ r e s u l t i n g ~ i n ~ a n ~}$ increase of the $\mathrm{cmc}$ due to repulsion between these two negatively charged species.

The formation of zein-SDS micelles at different concentrations of SDS above the $\mathrm{cmc}$ and the influence of $\mathbf{Z r}-\mathbf{K}$ 1:2 on these micellar structures was also followed by dynamic light scattering (DLS) to determine the particle size distribution in solution. As can be seen from the volume particle size distribution (VPSD) plots in Figure 7 (a), which take into account both the scattering intensity and size of particles in solution, $0.36 \mathrm{wt} \%$ SDS in $10 \mathrm{mM}$ phosphate buffer at $\mathrm{pH} 7.4$ gives rise to a peak corresponding to a hydrodynamic diameter $\left(\mathrm{d}_{\mathrm{H}}\right)$ of $3.6 \mathrm{~nm}$. This is 


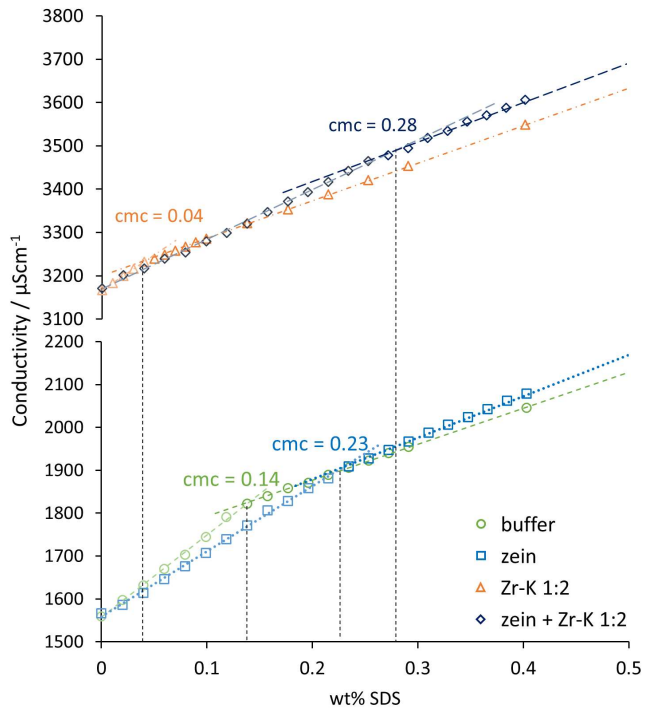

Figure 6. Plot showing the increase in conductivity upon increase in concentration of SDS from 0 to $0.5 \mathrm{wt} \%$ for solutions in $10 \mathrm{mM}$ phosphate buffer at $\mathrm{pH} 7.4$ without additives, with $0.2 \mathrm{mM}$ zein, with $4 \mathrm{mM} \mathrm{Zr-K} \mathrm{1:2} \mathrm{and} \mathrm{with} \mathrm{both}$ $0.2 \mathrm{mM}$ zein and $4 \mathrm{mM} \mathrm{Zr-K} \mathrm{1:2.} \mathrm{The} \mathrm{cmc}$ is labelled for each series next to the inflection point.

(a)
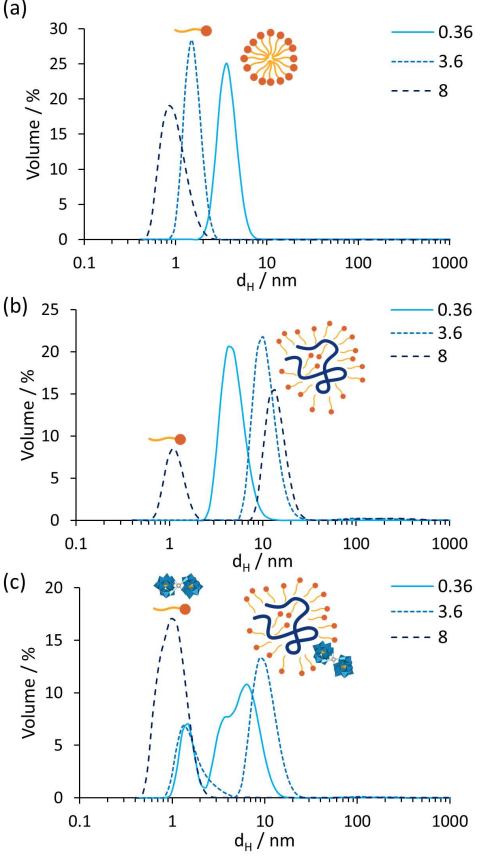

Figure 7. Volume particle size distribution (vPSD) of solutions in $10 \mathrm{mM}$ phosphate buffer at pH 7.4 with different concentrations of SDS $(0.36,3.6$ and $8 \mathrm{wt} \%$ ) (a) without additives, (b) with $0.2 \mathrm{mM}$ zein and (c) with $0.2 \mathrm{mM}$ zein and $4 \mathrm{mM}$ Zr-K 1:2.

approximately twice the length of a fully unfolded SDS molecule and therefore likely corresponds to spherical micelles. However, as the concentration of SDS was increased to $3.6 \mathrm{wt} \%$ or even 8 wt $\%$ the $d_{H}$ decreased to $1-1.5 \mathrm{~nm}$, which corresponds to the length of a single SDS molecule, suggesting that free SDS becomes the dominant species in solution, even though large micellar structures were still present, as evidenced from the intensity particle size distribution (iPSD) where large particles tend to dominate even at low concentrations due to their higher scattering ability (Figure S8). [57,58]

However, when $0.2 \mathrm{mM}$ zein was added to $0.36 \mathrm{wt} \%$ solution of SDS (Figure 7 (b)) a single peak was observed in the vPSD with a $d_{H}$ of $4.2 \mathrm{~nm}$, which is slightly larger than observed for the surfactant alone and likely indicates interactions between SDS and zein resulting in the formation of SDS-zein micelles. Furthermore, a single peak at $10.1 \mathrm{~nm}$ was observed for $0.2 \mathrm{mM}$ zein when the concentration of SDS was increased to $3.6 \mathrm{wt} \%$, due to the formation of larger micellar structures and further unfolding of the protein. In the presence of $8 \mathrm{wt} \%$ of SDS, a peak at an even higher $\mathrm{d}_{\mathrm{H}}$ of $13.5 \mathrm{~nm}$ was observed, indicating additional unfolding of the protein. A second smaller peak at 1.1 $\mathrm{nm}$ was also observed, which suggests that at high SDS concentrations the protein structure is saturated with SDS and some free SDS is also present in solution, which is in accordance with the conductivity measurements.

Addition of $4 \mathrm{mM}$ of $\mathrm{Zr}-\mathrm{K}$ 1:2 to $0.2 \mathrm{mM}$ zein in the presence of SDS (Figure 7 (c); Figure S8) resulted in disruption of the micellar structure and release of free SDS. This was evidenced by the a peak at $1-1.5 \mathrm{~nm}$ that was observed for all solutions and was the only peak observed in the vPSD for $8 \mathrm{wt} \%$ SDS. This is likely due to competitive binding to the protein resulting in an exchange between Zr-K 1:2 and SDS around the protein's surface. Moreover, with $0.36 \mathrm{wt} \% \mathrm{SDS}$, the main species in solution based on the vPSD had a $d_{H}$ of $6.5 \mathrm{~nm}$, which is higher than for zein alone and suggests that $\mathrm{Zr}-\mathrm{K} \mathrm{1:2}$ is able to interact with the protein, causing additional unfolding. However, with 3.6 $w t \%$ SDS no significant increase in the $\mathrm{d}_{\mathrm{H}}$ of the micellar structure was observed, which suggests that at this concentration of SDS, $\mathrm{Zr}-\mathrm{K} \mathbf{1 : 2}$ is less able to interact with the protein and cause changes to the micellar structure. It is plausible that the negatively charged head groups of SDS form a protective micellar shell around the protein repelling the negatively charged Zr-K 1:2 and preventing the POM from interacting as easily with the protein, which is in accordance with the observations from fluorescence spectroscopy and further explains the hydrolysis results.

\section{Speciation and Stability of Zr-K 1:2 followed by ${ }^{31} \mathrm{P}$ NMR}

The speciation and stability of the POM catalyst in solution under hydrolysis conditions (4 mM Zr-K 1:2 in $10 \mathrm{mM}$ phosphate buffer at $\mathrm{pH} 7.4$ and at $60^{\circ} \mathrm{C}$ ) in the presence of different amounts of SDS $\left(0.36,3.6\right.$ and $8 \mathrm{wt} \%$ ) was studied over time by ${ }^{31} \mathrm{P}$ NMR (Figure 8; Figures S9-14). The ${ }^{31} \mathrm{P}$ NMR spectra obtained from all solutions, regardless of the amount of SDS present in solution, showed two peaks at -14.50 and $-14.61 \mathrm{ppm}$. These peaks originate from the two phosphorous environments of $\mathrm{Zr}-\mathrm{K} \mathrm{1:2}$ $\left(\left[\mathrm{Zr}\left(\mathrm{\alpha}-\mathrm{PW}_{11} \mathrm{O}_{39}\right)_{2}\right]^{10-}\right)$ which are chemically inequivalent since the two Keggin units exhibit different bonding modes towards $\mathrm{Zr}(\mathrm{IV})$ ion with different bond lengths and bond angles (Figure 1).[59] In addition, a minor peak at $-10.60 \mathrm{ppm}$ was also observed from the beginning in all solutions, and could be assigned to the monolacunary Keggin structure $\left(\left[\alpha-\mathrm{PW}_{11} \mathrm{O}_{39}\right]^{7-;}\right.$; lac-K), which is known to form in phosphate buffer due to dissociation of $\mathbf{Z r - K}$ 1:2.[42,59] Furthermore, the amount of lac-K present in solution increased slightly with the amount of SDS present in solution 
( $11 \%$ of lac-K with $0.36 \mathrm{wt} \%$ SDS, $17 \%$ of lac-K with $3.6 \mathrm{wt} \%$ SDS and $21 \%$ of lac- $\mathrm{K}$ with $8 \mathrm{wt} \% \mathrm{SDS}$ after 1 day at $60^{\circ} \mathrm{C}$ ) suggesting that increasing the concentration of SDS favors the dissociation of $\mathrm{Zr}-\mathrm{K} \mathrm{1:2}$ and the loss of the $\mathrm{Zr}(\mathrm{IV})$ metal center. Hence, this loss of some of the $\mathrm{Zr}(\mathrm{IV})$ from the POM could additionally explain why the hydrolysis efficiency decreases with increasing concentration of SDS in solution as less of the catalytically active species is present in solution.[12] The monomeric $\mathrm{Zr}(\mathrm{IV})$ substituted POM, $\left[\mathrm{Zr}\left(\alpha-\mathrm{PW}_{11} \mathrm{O}_{39}\right)\right]^{3-}(\mathrm{Zr}-\mathrm{K} 1: 1)$, is known to be the catalytically active species and it should be formed in stoichiometric amounts by the dissociation of $\mathrm{Zr} \mathrm{1:2} \mathrm{into} \mathrm{lac-K} \mathrm{and}$ $\mathrm{Zr}-\mathrm{K}$ 1:1. A fast exchange between $\mathrm{Zr}-\mathrm{K}$ 1:2 and $\mathrm{Zr}-\mathrm{K}$ 1:1 in solution has been previously reported and reversible dissociation of Zr-K 1:2 to form Zr-K 1:1 becomes more favorable in the vicinity of the protein, as has been confirmed by single crystal $\mathrm{X}$-ray diffraction and theoretical calculations.[60,61] However, this fast exchange typically cannot be observed by ${ }^{31} \mathrm{P}$ NMR, most likely because $\mathrm{Zr}-\mathrm{K} \mathrm{1:1}$ is only stable in solution at very low $\mathrm{pH}$. Hence, the presence of a peak at $-10.60 \mathrm{ppm}$ without a corresponding peak for $\mathrm{Zr}-\mathrm{K}$ 1:1 indicates the irreversible loss of some of the $\mathrm{Zr}$ substituted POM. Nevertheless, no changes were observed in the ${ }^{31} \mathrm{P}$ NMR spectra upon incubating the samples for up to 12 days at $60{ }^{\circ} \mathrm{C}$, demonstrating the stability of the $\mathrm{POM}$ catalyst over time. Moreover, the presence of $0.2 \mathrm{mM}$ of zein in solution also had no influence on the stability of Zr-K 1:2 in solution over 12 days since the acquired ${ }^{31} \mathrm{P}$ spectra were the same in the presence and absence of zein (Figure S12-14).

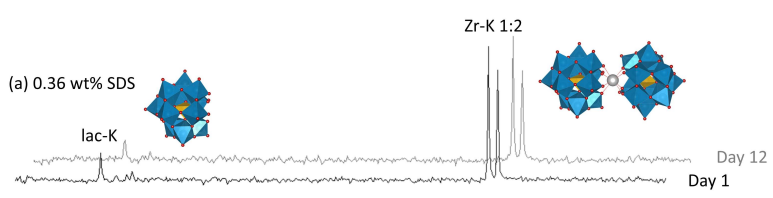

(b) $3.6 \mathrm{wt} \% \mathrm{SDS}$

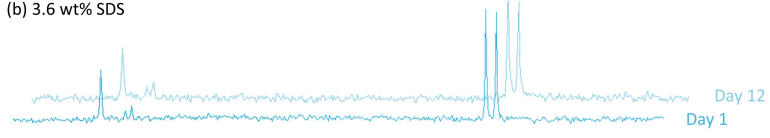

(c) $8 \mathrm{wt} \% \mathrm{SDS}$

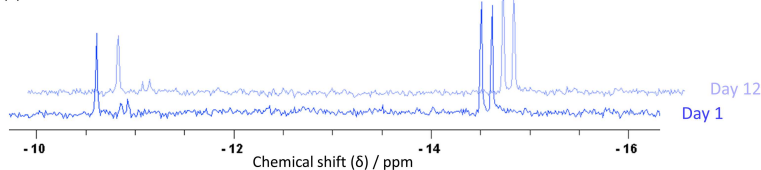

Figure 8. ${ }^{31} \mathrm{P}$ NMR spectra of $4 \mathrm{mM} \mathrm{Zr-K} \mathrm{1:2}\left(\left[\mathrm{Zr}\left(\alpha-\mathrm{PW}_{11} \mathrm{O}_{39}\right)_{2}\right]^{10-}\right)$ in phosphate buffer at pH 7.4 with (a) 0.36 , (b) 3.6 and (c) 8 wt\% SDS acquired after 1 day and 12 days of incubation at $60{ }^{\circ} \mathrm{C}$. Essentially no change was observed in the ${ }^{31} \mathrm{P}$ spectra over time indicating that $\mathrm{Zr}-\mathrm{K}$ 1:2 remained stable under these conditions, but more of the monolacunary Keggin structure $\left(\left[\alpha-\mathrm{PW}_{11} \mathrm{O}_{39}\right]^{7-}\right.$; lacK) was observed with increasing amount of SDS based on the relative integration of the peak at $-10.60 \mathrm{ppm}$.

\section{Proposed mode of interaction}

Hydrophobic amino acids, which are the major components of zein, make the protein insoluble in aqueous solutions, and the addition of ionic surfactants such as SDS is necessary for solubilization.[28,62] At very low concentrations of SDS below the $\mathrm{cmc}$, the protein is not soluble and is mostly involved in specific electrostatic interactions between the negatively charged head groups of SDS and the positively charged side chains of amino acids in the protein. As the concentration of SDS increases, the initial solubilization process starts, as all positively charged amino acids in the protein are saturated with SDS molecules, leading to hydrophobic interactions between the alkyl chains of SDS and hydrophobic patches of the protein. Unfolding of the protein structure with increasing concentration of SDS can then take place due to the repulsion between the negatively charged head groups of SDS and promoted by penetration of the hydrophobic tails of SDS deeper into the protein structure.[62] Eventually the protein structure becomes fully saturated, which was confirmed by DLS and conductivity measurements.

Based on the obtained results, a competitive binding model can be proposed for the interactions between zein, SDS and $\mathbf{Z r}$ K 1:2 in $10 \mathrm{mM}$ phosphate buffer, resulting in hydrolysis of the protein depending on the concentration of SDS (Figure 9). If $\mathbf{Z r}$ $K 1: 2$ is also present in solution, it competes with SDS for binding to the protein, which increases the $\mathrm{cmc}$ of the system and results in further unfolding of the protein structure. This results in a reversible exchange between $\mathbf{Z r - K}$ 1:2 and SDS around the protein surface which liberates free SDS into solution even at relatively low concentrations of SDS. Then, in the vicinity of the protein surface, $\mathbf{Z r - K ~ 1 : 2 ~ i s ~ a b l e ~ t o ~ d i s s o c i a t e ~ i n t o ~ t h e ~ c a t a l y t i c a l l y ~}$ active monomeric $\mathrm{Zr}-\mathrm{K}$ 1:1 species, which can interact with peptide bonds in positively charged patches of the protein and thereby selectively hydrolyze the protein as has been previously reported.[60,63] Since most of the amino acids in the protein are hydrophobic in nature, there is a limited number of positively charged amino acids in the protein which can interact with the negatively charged Zr-substituted POM. However, interactions between the POM and polar amino acids and even negatively charged amino acids of the protein can also occur via hydrogen bonding through water as a mediator, which has been previously confirmed by crystallographic studies.[60,61] Furthermore, POMs with relatively low charge density are known to behave as superchaotropes which can favorably interact with hydrophobic environments promoted by the release of water molecules in the hydration shell around the POM.[64,65] Hence, it is possible that the POM can also interact with hydrophobic regions of the protein.

As the concentration of SDS is increased further, the equilibrium shown in Figure $\mathbf{9}$ is shifted, impeding interactions between the POM and the protein. This results in the lack of any noticeable hydrolysis once the protein is fully saturated at $8 \mathrm{wt} \%$ of SDS due to repulsion of the POM by the dense and negatively charged protective shell formed by SDS around the protein. This is in accordance with the presence of free SDS at higher concentrations determined by conductivity measurements and DLS as well as with the lower binding constant for $\mathrm{Zr}-\mathrm{K} \mathrm{1:2}$ observed by fluorescence spectroscopy, despite the more unfolded structure of zein as seen by CD spectroscopy. Likewise, increasing the concentration of the POM in solution shifts the equilibrium to favor interactions between the POM and the protein, resulting in a higher hydrolysis efficiency. 


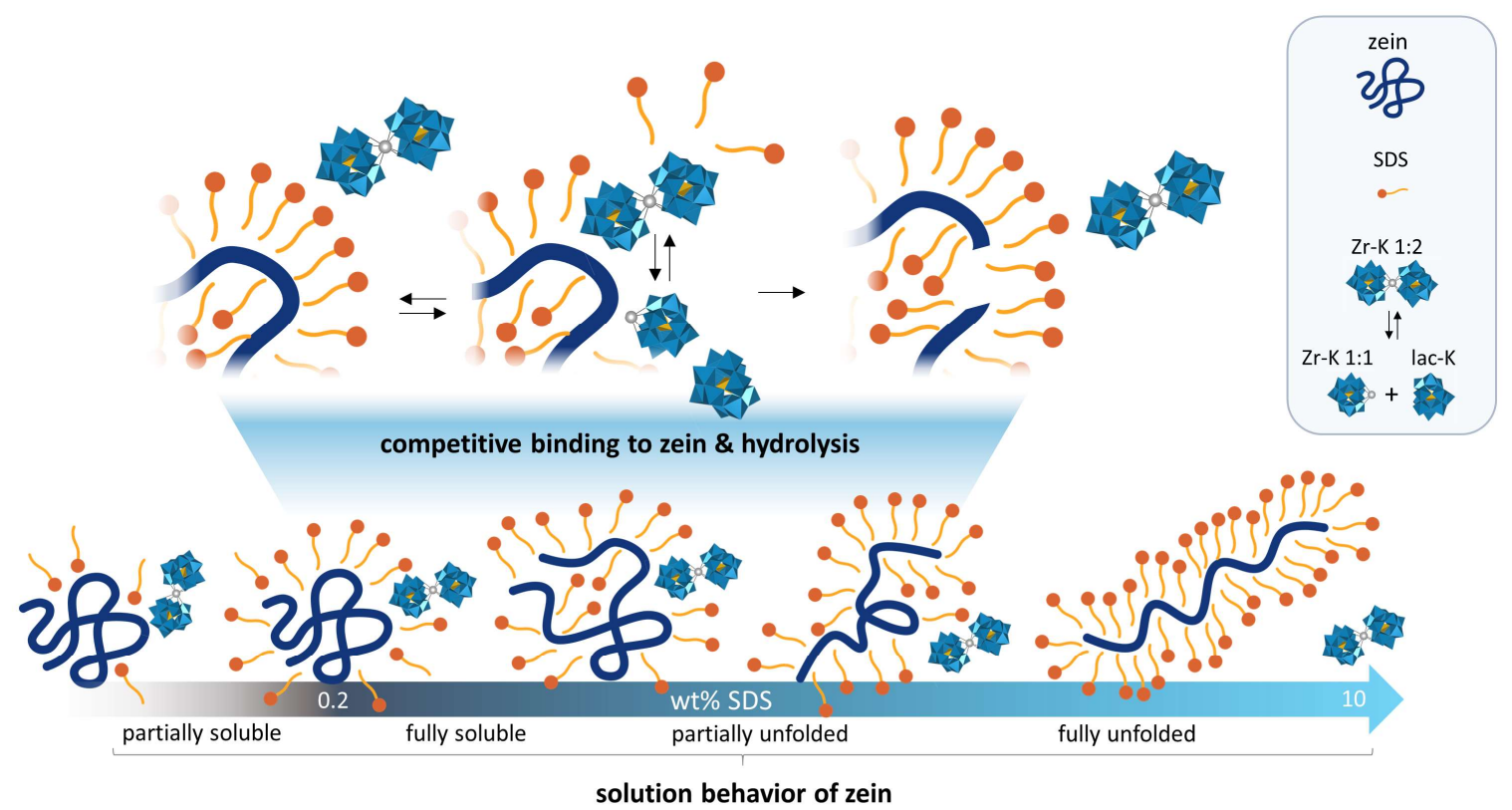

Figure 9. Schematic representation of the solution behavior of the ternary protein-POM-surfactant system in solution with increasing concentration of the surfactant. The protein (dark blue) is unfolded and solubilized by the surfactant (orange) which can exchange with the $\mathrm{POM}^{\text {(light blue WO}} \mathrm{W}_{6}$ octahedra, yellow $\mathrm{PO}_{4}$ tetrahedra and grey $\mathrm{Zr}(\mathrm{IV})$ metal center), resulting in hydrolysis of peptide bonds after dissociation of the POM into its catalytically active form.

Overall, the presence of a high concentration of SDS interferes with interactions between POM and protein regardless of the unfolding of the protein structure caused by the surfactant, since the dense micellar structure formed around the protein has a higher influence on the hydrolytic ability of the POM. This is likely in accordance with the previously reported decrease in the hydrolysis efficiency and/or the binding affinity observed for the hydrolysis of water-soluble proteins by $\mathrm{Zr}-\mathrm{K}$ 1:2 in the presence of SDS with respect to in the absence of surfactants.[22-24] However, an in-depth investigation or explanation of how interactions on a molecular level influence hydrolysis has not been provided until now. Hence, we suggest that a similar process as observed for zein also takes place for water-soluble proteins, since the presence of SDS molecules around the protein surface result in steric and electrostatic clashes with the POM. Therefore, rearrangement of the SDS molecules or their release into solution is necessary for the POM to be able to interact with the protein, thereby presenting an added energy barrier towards interaction, which can be detrimental in the case of the hydrolysis of soluble proteins, but is unavoidable in the case of insoluble proteins that require surfactants for solubilization. Nevertheless, by limiting the surfactant concentration to the minimum necessary, a reasonably high hydrolytic efficiency is still possible. Hence, a competitive binding model likely applies across a wide range of proteins including globular soluble proteins and unstructured partially soluble proteins, but the extent to which this hinders POM-protein interactions will depend on the structure of the surfactant, the $\mathrm{POM}$ and the protein.

\section{Conclusion}

In this study, the hydrolytic activity of a Zr-substituted polyoxometalate (Zr-K 1:2) toward a fully insoluble protein has been reported for the first time. Different concentrations of SDS, which was necessary to solubilize the protein, were probed in order to explore the influence of surfactant concentration on the hydrolysis reaction. It was found that $\mathrm{Zr}-\mathrm{K}$ 1:2 showed the highest activity when the protein was solubilized with low concentrations of SDS, resulting in the formation of 4 peptide fragments of around $10 \mathrm{kDa}$, which are in the range suitable for middle-down proteomics. In contrast, solubilization of zein with an excess of SDS resulted in no noticeable hydrolysis of the protein, even after prolonged incubation with $\mathrm{Zr}-\mathrm{K}$ 1:2, indicating that increasing the amount of SDS hindered the hydrolytic ability of the POM. The obtained results are consistent with fluorescence measurements, where the highest binding affinity of $\mathrm{Zr}-\mathrm{K} \mathrm{1:2}$ with zein was observed in the presence of a minimal amount of SDS. These differences in the hydrolytic activity and binding affinity of Zr-K 1:2 with increasing concentration of SDS can be attributed to changes in the zein-SDS micellar superstructure which were observed to form by conductivity and DLS measurements. Furthermore, a much lower $\alpha$-helical content was observed by CD spectroscopy in the presence of high concentrations of SDS, which is due to unfolding of the protein as more SDS molecules accommodate around the protein surface. DLS measurements indicated that at high concentrations of SDS the negatively charged polar heads of the anionic surfactant make a protective shell around the protein and hinder competitive binding of the POM with the protein.

In conclusion, this study has demonstrated that metalsubstituted POMs are able to selectively hydrolyze completely insoluble proteins when the proteins are solubilized using surfactants, and that the hydrolytic activity can be tuned by varying the concentration of the surfactant and the catalyst. Overall, the obtained results suggest that POM catalysts have potential as artificial proteases for the hydrolysis of insoluble proteins in middle-down proteomics studies, which could facilitate the determination of their structure, potentially impacting different fields of medicine and pharmacology. 


\section{Experimental Section}

Materials

N,N,N',N'-tetramethylethylenediamine (TEMED), ammonium persulphate (APS), phosphotungstic acid hydrate $\left(\mathrm{H}_{3}\left[\mathrm{PW}_{12} \mathrm{O}_{40}\right] \cdot \mathrm{xH}_{2} \mathrm{O}\right)$, sodium tungstate dihydrate $\left(\mathrm{Na}_{2} \mathrm{WO}_{4} \cdot 2 \mathrm{H}_{2} \mathrm{O}\right)$, tricine, disodium phosphate $\left(\mathrm{Na}_{2} \mathrm{HPO}_{4}\right)$, sodium, dodecyl sulfate (SDS), formaldehyde, glutaraldehyde, silver nitrate, sodium thiosulphate, glycerol, and bromophenol blue were purchased from Sigma-Aldrich (St. Louis, MO, USA). Zirconium oxychloride octahydrate and acetone were obtained from ChemLab (Zedelgem, Belgium). Aqueous hydrochloric acid (37\%), sodium hydrogen carbonate, and sodium carbonate were obtained from Acros organics (Fair Lawn, NJ, USA). Ethanol, methanol, aqueous ortho-phosphoric acid (85\%) glacial acetic acid, diethyalaminehydrochloride, and protein ladders were acquired from Thermo Fisher Scientific (Waltham, MA, USA). Monosodiumphosphate $\left(\mathrm{NaH}_{2} \mathrm{PO}_{4}\right)$ was purchased from VWR Chemicals (Radnor, PA, USA). Tris(hydroxymethyl)aminomethane (TRIS), acrylamide:bisacrylamide (29:1) solution $\quad(40 \%), \quad$ and acrylamide:bisacrylamide (19:1) solution (40\%) were procured from AppliChem Panreac (Darmstadt, Germany). Zein was obtained from J\&K Scientific (Beijing, China), 2-mercaptoethanol was purchased from Merck (Darmstadt, Germany). $\left[\mathrm{Zr}\left(\alpha-\mathrm{PW}_{11} \mathrm{O}_{39}\right)_{2}\right]^{10-}$ and $\left[\mathrm{A}-\alpha-\mathrm{PW}_{9} \mathrm{O}_{34}\right]^{7-}$ were synthesized following a slightly altered procedure from $[66,67]$

\section{Hydrolysis}

Solutions contain $0.2 \mathrm{mM}$ of zein solubilized with different concentrations of SDS (0.36, 3.6 and $8 \mathrm{wt} \%$ ), and with either $4 \mathrm{mM}$ or $20 \mathrm{mM}$ of Zr-K 1:2 were prepared in $10 \mathrm{mM}$ sodium phosphate buffer at $\mathrm{pH} 7.4$. Control solutions with $20 \mathrm{mM}$ of $\mathrm{Na} a_{9}\left[\alpha-\mathrm{PW}_{9} \mathrm{O}_{34}\right]$ and $0.36 \mathrm{wt} \%$ or $3.6 \mathrm{wt} \%$ of SDS were also prepared in the same way. The samples were incubated at $60^{\circ} \mathrm{C}$ in a Thermomixer (Eppendorf) for 10 days and aliquots were taken at different time points. SDS-PAGE was used to monitor the progress of the hydrolysis (4\% stacking gels and $18 \%$ resolving gels running in a $0.1 \mathrm{M}$ Tris-Tricine with $0.1 \%$ SDS running buffer). 5-10 $\mu \mathrm{L}$ of each sample were mixed with sample buffer $(5 \mu \mathrm{L})$ and heated at $95{ }^{\circ} \mathrm{C}$ for $5 \mathrm{~min} .10 \mu \mathrm{L}$ of the resulting solution was loaded to the gel. Unstained Page ruler protein ladder was used as a standard. Two SDS page gels were run at the same time with voltage of $200 \mathrm{~V}$, constant current set to $70 \mathrm{~mA}$ and maximum power set to $50 \mathrm{~W}$. The total running time was approximately $1.5 \mathrm{~h}$. The images of each gel were analyzed with Image Lab software (Bio-Rad).

\section{Fluorescence Spectroscopy}

Samples containing $0.2 \mathrm{mM}$ of zein solubilized in $0.36,3.6$ and $8 \mathrm{wt} \%$ of SDS were prepared in a $10 \mathrm{mM}$ sodium phosphate buffer at $\mathrm{pH} 7.4$. The concentration of $\mathrm{Zr}-\mathrm{K}$ 1:2 was increased gradually from 0 to $60 \mu \mathrm{M}$. A 10.0 $\mathrm{mm}$ quartz cuvette was used to record emission spectra with an Edinburgh Instruments FLS-980 spectrometer. The samples were excited at $275 \mathrm{~nm}$ and emission spectra were acquired from 280 to $450 \mathrm{~nm}$. The samples were kept at ambient temperature during the recording of the spectra.

\section{Circular Dichroism Spectroscopy}

Solutions containing $0.02 \mathrm{mM}$ of zein solubilized with different concentrations of SDS $(0.36,3.6$ and $8 \mathrm{wt} \%)$ were prepared in $10 \mathrm{mM}$ sodium phosphate buffer at $\mathrm{pH}$ 7.4. The concentration of $\mathrm{Zr}-\mathrm{K} \mathrm{1:2}$ was increased incrementally from 0 to $100 \mu \mathrm{M}$ in $20 \mu \mathrm{M}$ steps. The CD spectra were recorded with a JASCO-1500 spectrometer $20 \mathrm{~min}$ after the samples were prepared and transferred to $1 \mathrm{~mm}$ quartz cuvette. The resulting spectra are averaged over 3 accumulations with a bandwidth of $1 \mathrm{~nm}$. The buffer solution was measured for baseline correction. The samples were kept at a constant temperature of $25 \pm 0.1^{\circ} \mathrm{C}$ during the acquisition of all spectra.

\section{Particle Size Distribution}

Volume and intensity particle size distribution (vPSD and IPSD) of solutions in $10 \mathrm{mM}$ phosphate buffer at $\mathrm{pH} 7.4$ without additives, as well as with $0.2 \mathrm{mM}$ zein and $4 \mathrm{mM} \mathrm{Zr-K} \mathrm{1:2} \mathrm{(separately} \mathrm{and} \mathrm{combined),} \mathrm{in} \mathrm{the}$ presence of $0.36,3.6$ and $8 w t \%$ SDS were determined by dynamic light scattering at $25^{\circ} \mathrm{C}$. The backscattering of a $632.8 \mathrm{~nm}$ laser at $173^{\circ}$ was measured using a Zetasizer Nano ZSP (Malvern Panalytical Ltd., Malvern, UK). Before measuring, all solutions were prepared in buffer solutions filtered through a $0.2 \mu \mathrm{m}$ nylon filter and were then centrifuged for $15 \mathrm{~min}$ at $14 \mathrm{k} \mathrm{rpm}$ to remove any undesired large particles or dust. The hydrodynamic diameter $\left(\mathrm{d}_{\mathrm{H}}\right)$ of particles in solution was determined from the average vPSD or iPSD of 3 consecutive measurements as calculated from the dynamic light scattering correlation data by the equipment software provided by the manufacturer (Zetasizer Software 7.12, Malvern Panalytical Ltd., Malvern, UK).

\section{Conductivity}

The electrical conductivity of $15 \mathrm{~mL}$ solutions in $10 \mathrm{mM}$ phosphate buffer at $\mathrm{pH} 7.4$ was measured at room temperature to determine the critical micelle concentration (cmc) of SDS in the presence and absence of 0.2 $\mathrm{mM}$ zein and $4 \mathrm{mM} \mathrm{Zr-K} \mathrm{1:2} \mathrm{(separately} \mathrm{and} \mathrm{combined).} \mathrm{To} \mathrm{the} 15 \mathrm{~mL}$ solutions $30 \mu \mathrm{L}$ of $10 \mathrm{wt} \%$ SDS solution were added until reaching a total concentration of 0.3 or 0.4 wt $\%$ SDS in the solution, depending on when the $\mathrm{cmc}$ was observed, and then $180 \mu \mathrm{L}$ of $10 \mathrm{wt} \%$ SDS solution until the total amount of SDS in the solution was $1 \mathrm{wt} \%$. For measurements with a higher amount of SDS $15 \mathrm{~mL}$ solutions with 2-9 wt\% of SDS were preprepared separately. A S230 SevenCompact conductivity meter (MettlerToledo) with an InLab 731-ISM electrode (Mettler-Toledo) calibrated with a $1413 \mu \mathrm{Scm}^{-1}$ standard solution (Mettler-Toledo) was used for all the measurements. The solutions were stirred thoroughly upon adding SDS or zein and the solution was allowed to equilibrate before measuring.

\section{${ }^{31}$ P NMR Spectroscopy}

All ${ }^{31} \mathrm{P}$ NMR measurements to determine the stability of $\mathbf{Z r}-\mathrm{K}$ 1:2 were performed on a Bruker Avance $400(161.98 \mathrm{MHz})$ spectrometer. $500 \mu \mathrm{L}$ solutions of $4 \mathrm{mM} \mathrm{Zr-K} \mathrm{1:2} \mathrm{with} \mathrm{and} \mathrm{without} 0.2 \mathrm{mM}$ of zein in the presence of $0.36,3.6$ or $8 w t \%$ of SDS were prepared in $10 \mathrm{mM}$ phosphate buffer at $\mathrm{pH} 7.4$ and 2 drops of $\mathrm{D}_{2} \mathrm{O}$ were added. The solutions were incubated at $60{ }^{\circ} \mathrm{C}$ in between measurements. $25 \% \mathrm{H}_{3} \mathrm{PO}_{4}$ in $\mathrm{D}_{2} \mathrm{O}$ in a sealed capillary tube was used as an external reference for the measurements.

\section{Acknowledgements}

T.N.P.-V. thanks Science Foundation Flanders (FWO) and KU Leuven for funding. N.D.S. acknowledges KU Leuven for financial support, and D.E.S.M. acknowledges Science Foundation Flanders (FWO) for a PhD fellowship $(83523 / 1183021 \mathrm{~N})$

Keywords: catalysis $\cdot$ hydrolysis $\bullet$ insoluble proteins $•$ polyoxometalates - surfactants

[1] J. Song, FEBS Letters., 2009, 583, 953-959.

[2] J. Song, F1000Research., 2013, 2:94

[3] S. Trimpin, B. Brizzard, BioTechniques, 2009, 46(5), 409-419.

[4] X. Zhang, T. Wang, H. Luo, J. Y. Yang, Y. Deng, J. Tang, M. Q. Yang, BMC Syst. Biol., 2010, 4:S6.

[5] S. Tan, H. T. Tan, M. C. M. Chung, Proteomics, 2008, 8, 39243932.

[6] C. R. Sanders, J. K. Myers, Annu. Rev. Biophys. Biomol. Struct., 2004, 33, 25-51

[7] C. C. Wu, J. R. Yates, Nat. Biotechnol., 2003, 21, 262-267. 
[8] X. Meng, J. Clews, V. Kargas, X. Wang, R. C. Ford, Cell. Mol. Life Sci., 2017, 74, 23-38.

[9] M. N. Jones, Int. J. Pharm., 1999, 177(2), 137-159.

[10] P. Sweeney, H. Park, M. Baumann, J. Dunlop, J. Frydman, R. Kopito, A. McCampbell, G. Leblanc, A. Venkateswaran, A. Nurmi, R. Hodgson, Transl. Neurodegener., 2017, 6, DOI: 10.1186/s40035-017-0077-5.

[11] R. M. Kramer, V. R. Shende, N. Motl, C. N. Pace, J. M. Scholtz, Biophys J., 2012, 102(8), 1907-1915.

[12] A. Sap, L. Vandebroek, V. Goovaerts, E. Martens, P. Proost, T. N. Parac-Vogt, ACS Omega, 2017, 2(5), 2026-2033.

[13] B. Ericsson, P. Hegg, K. Mårtensson, J. Dispers. Sci. Technol., 1987, 8, 289-301.

[14] J. M. Gilmore, M. P. Washburn, J. Proteomics, 2010, 73, 20782091

[15] F. de Azambuja, J. Moons, T. N. Parac-Vogt, Acc. Chem. Res., 2021, 54, 1673-1684.

[16] N. I. Gumerova, A. Rompel, Chem. Soc. Rev., 2020, 49, 75687601.

[17] C. L. Hill, Chem. Rev., 1998, 98, 1-389

[18] A. Proust, R. Thouvenot, P. Gouzerh, Chem. Commun., 2008, 16, 1837-1852

[19] D-L. Long, E. Burkholder, L. Cronin, Chem. Soc. Rev., 2007, 36, 105-121.

[20] D-L. Long, R. Tsunashima, L. Cronin, Angew. Chem. Int. Ed., 2010, 49(10), 1736-1758.

[21] T. Quanten, P. Shestakova, D. Van Den Bulck, C. Kirschhock, T. N. Parac-Vogt, Chem. Eur. J., 2016, 22, 3775-3784

[22] T. Quanten, T. De Mayaer, P. Shestakova, T. N. Parac-Vogt, Front. Chem., 2018, 6, 372.

[23] N. D. Savić, D. E. Salazar Marcano, T. Quanten, T. N. Parac-Vogt, Inorganics, 2021, 9(4), 22.

[24] T. Quanten, N. D. Savić, T. N. Parac-Vogt, Chem. Eur. J., 2020 26, 11070-11179.

[25] A. O. Elzoghby, M. M. Elgohary, N. M. Kamel, Adv. Protein Chem. Struct. Biol., 2015, 98, 169-221.

[26] J. Menezes, K. A. Athmaselvi, Chapter 5, Report on Edible Films and Coatings, In Handbook of Food Bioengineering, Food Packaging and Preservation, 2018, Pages 177-212.

[27] V. Prasad, S. Felix, S. Srikanta, P. P. Biswas, S. Bose, Chapter 3, Implication of Nanoscience in the Food Processing and Agricultural Industries, In Handbook of Food Bioengineering, Impact of Nanoscience in the Food Industry, 2018, Pages 57-85.

[28] J. M. Ruso, N. Deo, P. Somasundaran, Langmuir, 2004, 20, 8988-8991.

[29] Y. Luo, T. Wang, Chapter 9, Pharmaceutical and Cosmetic Applications of Protein By-Products, Protein Byproducts, 2016, Pages 147-160.

[30] H. B. Krishnan, E. H. Coe Jr, Seed Storage Proteins, Encyclopedia of Genetics, 2001, 1782-1787.

[31] R. Shukla, M. Cheryan, Ind. Crops Prod., 2001, 13, 171-192.

[32] W. He, L. Tian, F. Fang, D. Chen, E. Federici, S. Pan, O. G. Jones, Food Chem., 2021, 348, 129035

[33] B. Kong, Y. L. Xiong, J. Agric. Food Chem., 2006, 54(16), 6059-6068.

[34] A. Cristobal, F. Marino, H. Post, H. van den Toorn, S. Mohammed, A. Heck, Anal. Chem., 2017, 89, 3318-3325.

[35] K. G. Kuznetsova, L. I. Levitsky, M. A. Pyatnitskiy, I. Y. Ilina, J. A Bubis, E. M. Solovyeva, V. G. Zgoda, M. V. Gorshkov, S. A Moshkovskii, J. Proteomics, 2021, 231, 104022

[36] A. Shevchenko, H. Tomas, J. Havlis, J. V. Olsen, M. Mann, Nat. Protoc., 2006, 1(6), 2856-2860.

[37] A. Ferjancic-Biagini, H. Gaertner, A. Puigserver, J. Agrlc. Food Chem. 1993, 41, 1152-1157.

[38] H. Saito, O. Shinmi, Y. Watanabe, K. Nishimura, K. Aso, Agric. Biol. Chern., 1988, 52(3), 855-856.

[39] M. L. A. Casella, J. R. Whitaker, J. Food Biochem., 1990, 14, 453-475

[40] H. G. T. Ly, G. Absillis, R. Janssens, P. Proost, T. N Parac-Vogt, Angew. Chem. Int. Ed., 2015, 54, 7391-7394.
[41] K. Stroobants, G. Absillis, E. Moelants, P. Proost, T. N. Parac-Vogt, Chem. Eur. J., 2014, 20, 3894-3897.

[42]. L. van Rompuy, N. D. Savić, A. Rodriguez, T. N. Parac-Vogt, Molecules, 2020, 25, 3472.

[43] A. Yammine, J. Gao, A. H. Kwan, Bio-protocol, 2019, 9(11), e3253.

[44] X. Wang, M. Fan, RSC Adv., 2019, 9, 5748-5755

[45] A. B. T. Ghisaidoobe, S. Chung, Int. J. Mol. Sci., 2014, 15(12), 2251822538

[46] R. Pan, Y. Zou, J. Wang, Z. Wan, J. Guo, J. Yang, X. Yang, Int. J. Food Sci. Technol., 2018, 53, 1622-1630.

[47] K. Stroobants, V. Goovaerts, G. Absillis, G. Bruylants, E. Moelants, P. Proost, T. N. Parac-Vogt, Chem. Eur. J., 2014, 20, 9567-9577.

[48] V. Goovaerts, K. Stroobants, G. Absillis, T. N. Parac-Vogt, J. Inorg. Biochem., 2015, 150, 72-80.

[49] V. Goovaerts, K. Stroobants, G. Absillis, T. N. Parac-Vogt, Phys. Chem. Chem. Phys., 2013, 15, 18378-18387.

[50] G. W. Selling, S. A. H. Hamaker, D. J. Sessa, Cereal Chem., 2007, 84 265-270.

[51] A. J. Miles, B. A. Wallace, Chem. Soc. Rev., 2016, 45, 4859-4872.

[52] T. T. Zheng, A. Boyle, H. R. Marsden, D. Valdink, G. Martelli, J. Raap, A. Kros, Org. Biomol. Chem., 2015, 13, 1159-1168.

[53] J. L. S. Lopes, A. J. Miles, L. Whitmore, B. A. Wallace, Protein Sci., 2014, 23(12), 1765-1772.

[54] E. Fuguet, C. Ràfols, M. Rosés, E. Bosch, Anal. Chim. Acta, 2005, 548, 95-100.

[55] A. Bhattarai, S. K. Shah, K. Limbu, Sci. World, 2014, 12(12), 41-43.

[56] T. Quanten, P. Shestakova, A. Kondinski and T. Parac-Vogt, Inorganics, 2018, 6, 112.

[57] Y. Mirgorod, A. Chekadanov, T. Dolenko, Chem. J. Mold., 2019, 14, 107-119.

[58] A. Ali, V. Bhushan, N. A. Malik and K. Behera, Colloid Journal, 2013 75, 357-365

[59] C. N. Kato, A. Shinohara, K. Hayashi and K. Nomiya, Inorg. Chem., 2006, 45, 8108-8119.

[60] L. Vandebroek, E. De Zitter, H. G. T. Ly, D. Conić, T. Mihaylov, A. Sap P. Proost, K. Pierloot, L. Van Meervelt, T. N. Parac-Vogt, Chem. Eur. J., 2018, 24, 10099-10108.

[61] A. Bijelic, A. Rompel, Coord. Chem. Rev., 2015, 299, 22-38

[62] N. Deo, S. Jockusch, N. J. Turro, P. Somasundaran, Langmuir, 2003 , 19(12), 5083-5088

[63] A. Sap, E. De Zitter, L. Van Meervelt, T. N. Parac-Vogt, Chem. Eur. J., 2015, 21, 11692-11695.

[64] K. I. Assaf, W. M. Nau, Angew. Chem. Int. Ed., 2018, 57, 1396813981

[65] T. Buchecker, P. Schmid, S. Renaudineau, O. Diat, A. Proust, A Pfitzner, P. Bauduin, Chem. Commun., 2018, 54, 1833-1836.

[66] M. N Sokolov, E. V. Chubarova, E. V. Peresypkina, A. V. Virovets, V. P Fedin, Russ. Chem. Bull., 2007, 56, 220-224.

[67] A. P. Ginsberg, Inorganic Synthesis vol. 27, John Wiley \& Sons, 1990 p. 100 


\section{Entry for the Table of Contents}

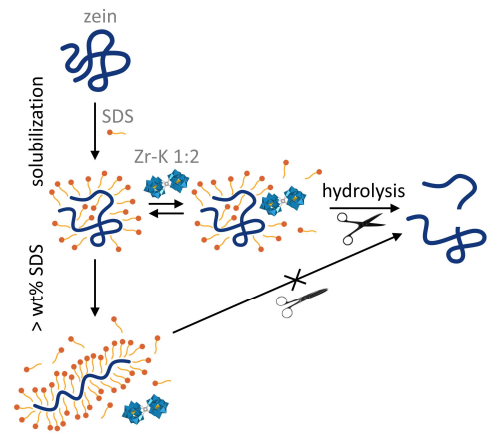

First report of the hydrolysis of a fully insoluble protein, zein, by a $\mathrm{Zr}(\mathrm{IV})$-substituted Keggin-type polyoxometalate complex in the presence of sodium dodecyl sulfate (SDS) via a competitive binding mechanism with a resulting dependence of the hydrolysis on the surfactant concentration. 